\title{
Project-based STEM-courses for engineering students
}

\author{
Lutsenko G., Podolian O., Ozhyndovych L. \\ Bohdan Khmelnytskyy National University of Cherkasy, Cherkasy, Ukraine
}

Received: $10.06 .2020 \quad$ Accepted: 24.06 .2020

\begin{abstract}
One of the world-recognized practices of modern higher education is the application of problem-based and project-based approaches to teaching STEM-disciplines. In case of integration of problem-based and project-based learning, the educational process is organized around the problem to be solved by students and stimulates them to find optimal strategies for solving, and project activities are chosen as a way of organizing work. The article describes the ongoing experience of implementation of project-based STEM-courses "Hydro- and Gas Dynamics" and "Applied Mechanics and Fundamentals of Design", which is part of training of engineering students of 151 Automation and Computer-integrated technologies speciality at the Bohdan Khmelnytskyy National University of Cherkasy during 2017-2019 academic years. The impact of problem-based and project-based approaches to teaching STEMdisciplines on the formation of professional and general competencies of future engineers had been analyzed. The dynamics of changes of personal and interpersonal skills of junior students during the teamwork on mono- and multidisciplinary projects had been studied. The case study method was chosen as the general research method, which corresponds to the number of research participants and the active role of researchers in the educational process. The results of surveys developed using the 5-point Likert scale, demonstrates that students mostly positively evaluate the projects and teamwork. The possibility of self-grouping, which made possible to form teams based on common interests and promote freer and more natural communication within the team, was the important factor of positive perception of project work. The disadvantages of the implemented approaches include the difficulties that manifested itself at the stage of students' planning of the project process. One of the reasons for this is the lack of previous experience in the realization of students' team projects. The introduction of multidisciplinary projects made it possible to optimize the workload of students working simultaneously on a project in two disciplines and increase the motivation to study the disciplines of the STEM cycle..

Key words: project-based learning, problem-based learning, teamwork, STEM, physics.
\end{abstract}

\section{Проектно-орієнтовані STEM-дисципліни для студентів інженерних спеціальностей}

Луценко Г. В., Подолян О. М., Ожиндович Л. М.

Черкаський національний університет імені Богдана Хмельницького, Черкаси, Україна

\begin{abstract}
Анотація. Однією з актуальних практик сучасної вищої освіти $€$ застосування проблемно- та проектноорієнтованих підходів до навчання STEM-дисциплін. В умовах інтеграції проблемно- та проектноорієнтованого навчання, освітній процес організовується навколо проблемного завдання, що виноситься на вирішення студентів, а проектна діяльність обирається як спосіб організації роботи. У статті висвітлюється досвід впровадження проектно-орієнтованого навчання курсів «Гідрогазодинаміка» і «Прикладна механіка та основи конструювання», що було складовою професійної підготовки фрахівців за інженерною спеціальністю 151 Автоматизація та комп'ютерно-інтегровані технології у Черкаському національному університеті імені Богдана Хмельницького протягом 2017-2019 навчальних років. У ході дослідження було проаналізовано вплив застосування проблемно- та проектно-оріентованих підходів до навчання STEM-дисциплін на формування фахових і загальних компетентностей майбутніх інженерів. Досліджувалася динаміка змін особистісних та міжособистісних якостей студентів молодших курсів у ході командної роботи над моно- та мультидисциплінарними проектами. Основним методом дослідження було обрано метод кейсів, що відповідає кількості учасників дослідження й активній ролі дослідників у освітньому процесі. Результати опитувань, розроблених з використанням 5-точкової шкали Лайкерта, показують, що студенти позитивно оцінюють командну роботу над проектом. Одним із чинників цього виявилася можливість самостійного об'єднання у
\end{abstract}

Corresponding Author: Lutsenko Galyna Vasylivna, Tel. +38 (067) 277-02-79. E-mail: LutsenkoG@gmail.com Bohdan Khmelnytsky National University of Cherkasy, 79, blvd. Shevchenko, Cherkasy

Вiдnовідальний автор: Луценко Галина Василівна, Тел. +38 (067) 277-02-79. E-mail: LutsenkoG@gmail.com Черкаський національний університет імені Богдана Хмельницького, 79, бульв. Шевченка, Черкаси 
групи, що уможливило формування команд за спільними інтересами і сприяло вільнішому та природнішому спілкуванню в межах команди. До проблемних моментів впроваджуваних підходів належать труднощі, що виникали на етапі самостійного планування ходу виконання проекту. Однією з причин цього є відсутність попереднього досвіду практики реалізації студентських проектів. Упровадження мультидисциплінарних проектів дало можливість оптимізувати навантаження студентів, які працюють одночасно над проектом із двох дисциплін і посилити мотивацію до вивчення дисциплін STEM-циклу.

Ключові слова: проектно-орієнтоване навчання, проблемне навчання, робота в команді, STEM, фрізика.

\title{
Проектно-ориентированные STEM-дисциплины для студентов инженерных специальностей
}

\author{
Луценко Г. В., Подолян О. М., Ожиндович Л. М. \\ Черкасский национальный университет имени Богдана Хмельницкого, Черкассы, Украина
}

\begin{abstract}
Аннотация. Одной из актуальных практик современного высшего образования является применение проблемно и проектно ориентированных подходов к обучению STEM-дисциплин. В условия интеграции проблемно и проектно ориентированного обучения, образовательный процесс организуется вокруг проблемного задания, которое выносится на решение студентам, а проектная деятельность избирается как способ организации работы. В статье описывается опыт внедрения проектно ориентированного обучения курсов «Гидрогазодинамика» и «Прикладная механика и основы конструирования», что являлось составляющей профессиональной подготовки специалистов по инженерной специальности 151 Автоматизация и компьютерно-интегрированные технологии в Черкасском национальном университете имени Богдана Хмельницкого в течении 2017-2019 учебных годов. В ходе исследования было проанализировано влияние использования проблемно и проектно ориентированных подходов к обучению STEM-дисциплин на формирование профессиональных и общих компетентностей будущих инженеров. Была исследована динамика изменений личностных и межличностных качеств студентов младших курсов в ходе командной работы над моно- и мультидисциплинарными проектами. В качестве основного метода исследования был выбран метод кейсов, что соответствует количеству участников исследования и активной роли исследователей в образовательном процессе. Результаты опросов, разработанных с использованием 5-точковой шкалы Лайкерта, показывают, что студенты положительно оценивают командную работу над проектом. Одним из факторов этого является возможность самостоятельного объединения в группы, что сделало возможным формирование команд по общим интересам и способствовало свободному и более естественному общению в пределах команды. К проблемным моментам следует отнести трудности, которые возникали для студентов на этапе самостоятельного планирования хода выполнения проекта. Одной из причин этого является отсутствие предыдущего опыта практики реализации студенческих проектов. Внедрение мультидисциплинарных проектов позволило оптимизировать нагрузку студентов, которые работают одновременно над проектом по двум дисциплинам и усилить мотивацию к изучению дисциплин STEM-цикла.
\end{abstract}

Ключевые слова: проектно ориентированное обучение, проблемное обучение, работа в команде, STEM, физика.

\section{Bcmyn}

Серед цивілізаційних викликів людства у XXI столітті, відповіді на які безпосередньо пов'язані з професійною діяльністю інженерів, дослідники відзначають інтенсивний розвиток технологій, кліматичні зміни, інформаційну безпеку тощо [1]. Перераховані виклики, у своєму поєднанні, формують якісно нові вимоги до професійних якостей випускників інженерних спеціальностей, зокрема їх конкурентоспроможності при працевлаштуванні [2].

Сучасні інженери потребують інноваційних знань, навичок та компетентностей, серед яких навички з вирішення комплексних проблем, управління проектами, комунікаційні навички, робота в команді, навчання упродовж життя, підприємництво, етика тощо [3]. Для фахівців, що працюють у складних і невизначених умовах (або VUCA-умовах), на перший план виходить досвід роботи над мультидисциплінарними проектами, спрямованими на вирішення слабкоформалізованих проектних завдань реального світу [4].

Наразі, формуванням та оновленням вимог до підготовки майбутніх інженерів займаються професійні спілки інженерів різних країн, наприклад, АBET, FEANI, EC тощо [5]. Аналізуючи тенденції подальшого розвитку інженерної освіти з метою визначення їх максимально перспективних напрямів, у звіті Р. Грехем виділено чотири ключові риси, дотримання яких дозволить університетам претендувати 
на лідируючі позиції у контексті забезпечення якості професійної підготовки майбутніх інженерів. Наведемо їх перелік і короткий огляд [6]:

1. Поєднання цифрових технологій та активного навчання студентів для забезпечення високоякісної студентоцентрованої професійної підготовки.

2. Нарощування гнучкості, можливостей вибору та диверсифікація інженерних освітніх програм. Серед міркувань, висловлених на підтримку саме цього аспекту, цікавою є думка, що сучасна інженерна освіта, окрім фундаментальних речей, має приділяти увагу великому обсягу інших тем і видів діяльності, пропонуючи, таким чином, можливість для студентів обрати шлях, оптимальний з точки зору їх схильностей і професійних інтересів.

3. Поєднання в освітніх програмах міждисциплінарного навчання, досвіду, значимого з глобальної перспективи, та використання інженерії як рушійної сили позитивних соціальних змін.

4. Усвідомлення того, що ключові освітні практики, серед яких інтеграція власне навчання і професійної діяльності, а також проектні підходи у сфері інженерних завдань, $є$ не $є$ рутинними компонентами, а дозволяють студентам осмислювати, контекстуалізувати й розбудовувати професійні якості упродовж усього циклу навчання.

Загальні тенденції, яким підкоряється реформування української системи вищої інженерної освіти, залишаються незмінними - спрямованість на повноцінне впровадження вимог та рекомендацій Болонського процесу, долучення до якого для України відбулося ще в 2005 році. Така діяльність передбачає, зокрема, модернізацію освітніх програм підготовки майбутніх інженерів шляхом формулювання чітких та вимірюваних результатів навчання, а також дослідження і впровадження дієвих студентоцентрованих педагогічних підходів, що дозволять ефективно формувати визначені компетентності. Зазначимо, що все ж навіть найдосконаліша освітня програма не може бути належним чином використана чи, сформульовані в ній програмні результати навчання не можуть бути досягнуті, за відсутності цілеспрямованої педагогічної діяльності, яка включає в себе вибір та впровадження інноваційних педагогічних технологій, що дозволять відійти від традиційної дисциплінарно орієнтованої парадигми навчання та викладання, що залишається переважаючою для більшості закладів вищої освіти України, зокрема й інженерної спрямованості.

У випадку інженерної освіти дотримання дисциплінарно орієнтованої парадигми пов'язане з тим, що, на думку більшості викладачів, майбутні інженери потребують насамперед ґрунтовних знань 3 фундаментальних дисциплін природничо-математичного циклу. На противагу цьому, опитування, які проводилися в 2010-2016 роках [7, 8, 9], показують, що з точки зору українських працедавців, випускникам інженерних спеціальностей критично бракує інших якостей, а саме, вміння працювати в команді, вміння спілкуватися та співпрацювати з експертами з різних галузей тощо.

Викладене вище визначає підстави для пошуку найкращих практик і впровадження інноваційних та орієнтованих на студентів підходів до навчання й викладання, які при цьому будуть враховувати специфріку української системи інженерної освіти.

Аналіз сучасних джерел показує, що проблемно-орієнтоване та проектно-орієнтоване навчання $є$ визнаними на світовому рівні педагогічними підходами, що активно упроваджуються в підготовці студентів різних спеціальностей [10]. Попри той факт, що в багатьох працях для їх позначення використовується однакова абревіатура - PBL, i попри безсумнівну спорідненість їх засадничих положень, вони мають різну історію розвитку [11].

У випадку обох підходів, освітній процес організовується навколо проблеми, що виноситься на вирішення студентів та стимулює їх до пошуку оптимальних стратегій вирішення, а проектна діяльність обирається як спосіб організації роботи $[12,13]$. Традиційно перший досвід упровадження проблемноорієнтованого навчання датується кінцем 60-х років XX століття. Наразі, проблемно-орієнтоване навчання характеризується гнучкістю та різноманіттям і може впроваджуватися найрізноманітнішими способами на базі різних дисциплін, освітніх програм підготовки та навчальних закладів у цілому. Проблемно-орієнтоване навчання - це освітня парадигма, яка характеризується наступними властивостями: проблема як основа навчання та його відправна точка; викладач, що виступає радше в якості консультанта; робота виконується студентами в малих групах [14, 15].

Визначити стартову точку впровадження проектно-орієнтованого навчання в освітній процес достатньо складно, оскільки підготовка фрахівців інженерного та природничо-математичного профілів у 
вищій школі завжди містила складову, пов'язану із цілеспрямованим використанням отриманих знань на практиці [16]. Серед рекомендацій, пов'язаних з організацією проектно-орієнтованого навчання, ключовими $€[17]$ :

- розвиток студентської творчості та інноваційності мислення;

- звернення до проблем, що є слабко визначеними та не мають наперед відомого розв'язку;

- опанування методології інженерного проектування;

- уміння сформулювати та описати поставлену задачу з використанням зовнішнього та внутрішнього представлення;

- уміння використовувати альтернативні підходи до фрормулювання та вирішення проблем;

- розвиток гнучкості й системності мислення.

У контексті сучасних підходів до навчання, основою проблемно-орієнтованого і проектноорієнтованого навчання є положення конструктивізму відповідно до яких знання не може бути передане, а конструюється самим студентом на основі вже сформованих знань та уявлень [18]. Дослідники відзначають, що кількість праць, присвячених питанням упровадження проблемно-орієнтованого й проектно-орієнтованого навчання залишається стабільно високою [19].

Варто зазначити, що проблемно-орієнтоване навчання і проектно-орієнтоване навчання можуть бути складовою й традиційного, предметно орієнтованого освітнього процесу. При цьому, на відміну від студентоцентрованого навчання, викладач виконує керівні функції, визначаючи мету та завдання проекту, методи та засоби вирішення й оцінюючи кінцевий результат. Таким чином, проблемноорієнтоване навчання розглядається як узагальнена освітня концепція, а проектно-організоване навчання - як один із інструментів досягнення цілей [12].

Наголосимо, що впровадження окремих проектів у рамках вивчення окремих дисциплін, $\epsilon$ важливою діяльністю, однак цього недостатньо для того, щоб стверджувати, що навчання є проектноорієнтованим. Модернізація освітніх програм є комплексним завданням. Визначаючи ключові чинники, що впливають на цей процес, дослідники виділяють зовнішні (зміна вимог до навичок майбутніх інженерів загалом, потреба адаптувати чинні програми доля успішного проходження акредитації тощо) та внутрішні (зміна бачення освітньої програми на рівні викладачів, зміна адміністративних вимог, зменшення кількості вступників тощо) складові [20].

Як зазначено в статті [19], власне саме бачення освітньої програми трансформувалося від простого переліку навчальних курсів до плану їх викладання до складної моделі, що пов'язує змістове наповнення, програмні результати навчання, студентську й викладацьку діяльність тощо. Наголошуючи на складності роботи з оновлення освітніх програм, дослідники виділяють декілька ключових стратегій, що реалізовуються в закладах освіти: приєднання (an add-on strategy), інтеграції (an integration strategy) і перебудови (a re-building strategy) [21].

Стратегія приєднання, відповідаючи ідеям академічної свободи університетів, як правило відображає дуже лімітовані зміни, коли окремі компоненти додаються чи модифікуються, без розгляду й впровадження змін до всієї освітньої програми. Прикладом можуть бути нові курси за вибором, що пропонуються студентам. Як правило, ініціаторами таких змін $є$ окремі викладачі чи невеликі колективи викладачів. Інтеграційна стратегія спрямована на зміну складових освітньої програми й грунтується на обміні ідеями та їх поширенні уже за підтримки керівництвом університету. Найбільш істотні зміни досягаються при упровадженні змін на організаційному рівні, коли використовується стратегія цілковитої перебудови. Такі зміни стосуються освітньої програми у цілому й дозволяють досягати змін на концептуальному рівні [21].

Метою нашого дослідження є розробка інтегрованих підходів до впровадження проблемноорієнтованого та проектно-орієнтованого навчання STEM-дисциплін студентів інженерної спеціальності та вивчення їх впливу формування професійних якостей студентів. До ключових питань дослідження належать наступні:

- Як студенти молодших курсів інженерної спеціальності сприймають впровадження проектноорієнтованих підходів при навчанні STEM-дисциплін?

- Які фрахові та загальні компетентності, на думку студентів, розвиваються у ході виконання проектних завдань зі STEM-дисциплін? 
Ґрунтуючись на попередньому досвіді упровадження елементів проектно-орієнтованого і проблемно-орієнтованого навчання, ми вважаємо за необхідне зосередитися на пошуку й відпрацюванні кращих практик у рамках інтеграційної стратегії, очікуючи, що такі стратегії можуть бути ефективно використані при підготовці студентів не лише інженерних, але й природничо-математичних спеціальностей при навчанні STEM-дисциплін.

\section{II Матеріал і методи дослідження}

Черкаський національний університет імені Богдана Хмельницького здійснює підготовку студентів за інженерною спеціальністю 151 Автоматизація та комп'ютерно-інтегровані технології (АКІТ) 3 присвоєнням освітнього ступеню бакалавра починаючи з 2003 року. Дисципліни природничо-наукового циклу для спеціальності 151 АКІТ включають, насамперед, курс «Фізика» - 18 кредитів та вибрані розділи фрізики з урахуванням особливостей спеціальності 151 AKIT, а саме, «Прикладна механіка та основи конструювання» - 4 кредити, «Гідрогазодинаміка» - 4 кредити, «Теоретична механіка» - 3 кредити, «Електротехніка та електромеханіка» - 5 кредитів, «Термодинаміка і теплотехніка» - 4 кредити, що в сумі складає 20 кредитів. У відсотковому співвідношення фізика та її вибрані розділи становлять майже $16 \%$ навантаження студентів.

Перераховані вище природничо-наукові дисципліни, для позначення сукупності яких усе частіше використовується абревіатура STEM - science, technology, engineering, and mathematics, $\epsilon$ фундаментальною складовою підготовки майбутніх інженерів у сфері автоматизації [22]. Поряд з цим, затеоретизовані підходи до їх навчання і викладання шкодять їх повномірній інтеграції та негативно впливають на мотивацію студентів. Важливо також дотримуватися наступності у навчанні дисциплін природничо-наукового циклу, уникаючи дублювання окремих тем.

Традиційно для інженерних освітніх програм, вивчення вибраних розділів фрізики здійснюється протягом перших 4-5 семестрів. Така ситуація, властива більшості українських 3ВО, узгоджується 3 практикою інших країн [17]. Як правило, освітні програми підготовки майбутніх інженерів грунтуються на моделі, за якою вивчення інженерних дисциплін розпочинається лише після фрормування ґрунтовних засад у сфері природничо-математичних дисциплін. На жаль, така ситуація призводила до проблем 3 формування практично орієнтованих професійних якостей.

Поряд 3 цим, досвід впровадження інженерних проектів для студентів молодших курсів виявляється надзвичайно корисним. Важливо, що у випадку впровадження проектно-орієнтованого навчання для студентів молодших курсів, мова йде не про зміну переліку предметів, а, що набагато важливіше, на зміну підходів до навчання й викладання в цілому, коли потреби студента, його мотиваційні фрактори стають аспектом обов'язковим до врахування.

Викладене вище послугувало безпосереднім чинником для переформатування у 2017-2018 та 2018-2019 навчальних роках практики навчання STEM-дисциплін «Гідрогазодинаміка» (Проект 1) та «Прикладна механіка та основи конструювання» (Проект 2) на засадах проблемно- і проектноорієнтованого навчання. Нижче, особливості реалізації кожного із проектів описано детальніше. Зважаючи, що такий досвід був новим як для викладацького складу кафедри AKIT, так і для студентів, увага зосереджувалася на накопиченні інформації стосовно відгуків студентів за матеріалами проектів і порівнянні досвіду впровадження монодисциплінарного та мультидисциплінарного проектів.

До обмежуючих фракторів нашого дослідження слід віднести відносно невелику кількість студентів у групах. Це послугувало фактором вибору методу кейсів (case-study) у якості основного методу дослідження. Метод кейсів є особливим випадком в освітніх дослідженнях, який реалізовується для ілюстрації загальних принципів, фактично відображаючи характеристики певного явища "в дії" [23, 24]. При цьому, відокремленими досліджуваними об'єктами можуть виступати студент, група, інститут, університет тощо. Незважаючи на певну методологічну невизначеність, що спостерігається для методу кейсів, він $є$ потужною дослідницькою стратегією, яка має важливе практичне значення і дозволяє здійснювати глибинні дослідження одиничних ситуацій з метою осягнення значно ширшого класу подібних випадків. Серед ознак методу кейсів виділяють наступні [23]:

- він охоплює все різноманіття описів, що застосовуються до досліджуваної ситуації;

- він забезпечує хронологічне представлення подій, що відповідають досліджуваному випадку;

- у у ньму поєднуються опис подій та їх аналіз; 
- він фокусується на окремих учасниках дослідження чи їх групах та намагається зрозуміти їх ставлення до досліджуваних подій;

- у ньому висвітлюються конкретні події, що мають відношення до справи;

- дослідник є учасником процесів, що відбуваються.

Особливістю методу кейсів $є$ гнучкість дослідницького підходу, що дозволяє досліднику коригувати стратегію поведінки при надходженні нових емпіричних даних. Наслідком $є$ також принцип мультиметодичності, що виражається в застосуванні широкого спектру дослідницьких технік і джерел інформації. У випадку педагогічних досліджень такими джерелами можуть виступати освітні програми, навчальні плани, навчально-методичні матеріали, відомості про академічну успішність, інтерв'ю та опитування тощо. Для даної стратегії актуально $є$ перехресна перевірка даних з використанням процедури тріангуляції - застосування різних методів і джерел для подальшого аналізу. Тріангуляція може стосуватися процедури накопичення даних, дослідницької діяльності та методології [25]. У нашому випадку використовується дослідницька тріангуляція, коли схожі ситуації розглядаються групою вчених.

Для оцінювання сприйняття студентами впроваджуваних проектних підходів ми використовували опитувальники, розроблені із використанням п'яти-точкової шкали Лайкерта [26].

Розглянемо детальніше перебіг впроваджуваних проектів.

Проект 1. Дисципліна «Гідрогазодинаміка» відноситься до нормативного циклу в навчальному плані підготовки бакалаврів спеціальності 151 АКІТ. Ї̈̈ вивчення здійснюється на другому році навчання. Загальна кількість кредитів ЄКТС, передбачених навчальним планом - 4 (120 годин). Розподіл годин у рамках дисципліни наступний:

- аудиторна робота, що включає в себе лекційні та практичні заняття - 40 годин,

- самостійна робота - 80 годин.

Ефективне використання годин, що відводяться на самостійну роботу студентів, $є$ актуальною задачею, вирішення якої допомагає перейти від формального виділення цих годин на "абстрактні" види роботи студентів до їх реального наповнення.

У рамках аудиторних занять студенти прослуховують лекційний курс за основними темами, визначеними навчальною програмою дисципліни, а також оволодівають навичками розв'язання задач під час практичних занять. Навчальний час, визначений для самостійної роботи студентів, в якості експерименту було вирішено використати, організувавши роботу студентів над декількома проектами в малих групах.

Серед компетентностей, набуття яких очікується за результатами опанування дисципліни, виділимо ті, фрормування яких інтенсифікується у ході проектної діяльності студентів (Табл. 1) . Для загальних компетентностей ми використовували класифікацію за видами та формулювання, що відповідають матеріалам Tuning [27, 28].

Табл. 1. Приклад очікуваних компетентностей

\begin{tabular}{|c|c|c|c|}
\hline \multirow{2}{*}{ Фахові компетентності } & \multicolumn{3}{|c|}{ Загальні компетентності } \\
\cline { 2 - 4 } & Інструментальні & Міжособистісні & Системні \\
\hline Вирішення типових задач & $\begin{array}{c}\text { Аналіз отриманих } \\
\text { результатів }\end{array}$ & Робота в команді & Самоорганізація \\
\hline $\begin{array}{c}\text { Використання сучасного } \\
\text { інструментарію галузі }\end{array}$ & $\begin{array}{c}\text { Використання сучасного } \\
\text { програмного } \\
\text { забезпечення }\end{array}$ & $\begin{array}{c}\text { Критичність і } \\
\text { самокритичність }\end{array}$ & $\begin{array}{c}\text { Презентація } \\
\text { результатів } \\
\text { роботи }\end{array}$ \\
\hline $\begin{array}{c}\text { Застосування методів } \\
\text { математичного та фрізичного } \\
\text { моделювання }\end{array}$ & $\begin{array}{c}\text { Спілкування іноземною } \\
\text { мовою }\end{array}$ & $\begin{array}{c}\text { Міжособистісна } \\
\text { взаємодія }\end{array}$ & $\begin{array}{c}\text { Управління } \\
\text { проектами }\end{array}$ \\
\hline $\begin{array}{c}\text { Застосування знань у } \\
\text { практичних ситуаціях }\end{array}$ & $\begin{array}{c}\text { Пошук, огляд та аналіз } \\
\text { актуальних публікацій }\end{array}$ & & $\begin{array}{c}\text { Адаптація і дії в } \\
\text { новій ситуації }\end{array}$ \\
\hline
\end{tabular}


Розглядаючи проектно-орієнтоване навчання, необхідно звернути увагу на те, що в основу технології його реалізації для навчання дисциплін природничо-наукового циклу, покладено дослідну роботу студентів, яка вибудовується на засадах співтворчості студентів та викладачів. Зрозуміло, що студенти молодших курсів (а точніше I - III) ще не спроможні повністю включатися до дослідної роботи внаслідок недостатньої професійної і наукової підготовки. Але, на нашу думку, все ж доцільно залучати їх до пошуково-дослідницької роботи, оскільки репродуктивна самостійна робота не може бути достатньо ефективною під час фрормування самостійності як професійної якості особистості.

Загальна кількість студентів, залучених до дослідження в 2017-2018 навчальному році склала 19 осіб; у 2018-2019 навчальному році - 25 осіб. Студентам було запропоновано на вибір наступні проблемні завдання: «Проектування водогону для крапельного поливу ґрунту», «Проектування кімнатного фронтану 3 можливістю зміни висоти стовпа рідини» та «Гідравлічний розрахунок водопроводу багатоповерхівки». Ще одна тема була запропонована самими студентами, а саме «Проектування трубопровідної мережі при монтажу теплої підлоги у будинку».

Студенти самостійно об'єднувались у робочі групи по 4-6 осіб відповідно до обраної тематики проекту. Такий спосіб формування груп $є$ природнім і самоорганізовуючим, що враховує певні психологічні аспекти особистої взаємодії між студентами, дозволяє об'єднати людей за спільними інтересами і сприяє вільнішому та природнішому спілкуванню в межах групи. Зрозуміло, що завжди буде певний відсоток студентів, які не примкнуть до жодної з груп. Причини для цього можуть бути абсолютно різні: від банальної незацікавленості тематикою дослідження, до небажання працювати в команді, що випливає з певних психологічних особливостей окремої людини. Так, у нашому випадку, загальна кількість осіб, що висловили бажання попрацювати над одним з групових проектів - 36 осіб, що становить 81\% від загальної кількості студентів на потоках (у 2017-2018 н.р. - 15 осіб; у 2018-2019 н.р. -21 особа).

Для успішного виконання завдання студентам потрібно було визначити необхідні закони і рівняння гідродинаміки, що описують процеси руху рідин для кожного з випадків; виконати й оформити теоретичні розрахунки з обов'язковим виконанням схематичних креслень взаємного розташування трубопроводів, накопичувальних баків, насосів тощо та провести економічну оцінку практичної реалізації даного проекту.

Під час захисту проектів кожній робочій групі пропонувалося протягом 10-15 хвилин представити основні результати їх роботи у вільній формі, але з обов'язковим використанням наочних матеріалів (зображення, відеоматеріали, діаграми, графіки і т.п.). Після виступу кожної групи студенти заповнюють анкету, що дозволяє оцінити їх ставлення до проектної діяльності, складнощі з якими вони зіткнулися в процесі роботи та зацікавленість надалі працювати в такому форматі.

Проект 2. Створення веб-програм для здійснення фізичних розрахунків було визначене як завдання для студентів другого курсу спеціальності 151 АКІТ у рамках міждисциплінарного проекту 3 предметів «Прикладна механіка і основи конструювання» та «Технології розробки програмного забезпечення комп'ютерно-інтегрованих систем» [11].

«Прикладна механіка та основи конструювання» $€$ нормативною дисципліною циклу професійної підготовки за спеціальність 151 АКІТ, на вивчення якої відводиться 4 кредити ЄКТС. Завданням дисципліни є вивчення методів типових інженерних розрахунків; специфіки використання техніки при різних видах деформацій і навантажень; основних фрізико-механічних властивостей матеріалів та їх поведінку за різних умов тощо. Дисципліна «Технології розробки програмного забезпечення комп'ютерно-інтегрованих систем», що вивчається в тому ж семестрі, є дисципліною за вибором 3ВО циклу професійної підготовки. Розпочинається опанування дисципліни з вивчення модуля «Системи керування вмістом», обсяг якого - 5 кредитів (150 годин). Завданням дисципліни є вивчення сучасних технологій розробки веб-сервісів.

Ураховуючи різний рівень підготовки у сфері програмування та веб-програмування, студентам було запропоновано реалізувати проект, у рамках якого вони, використовуючи довільну систему керування вмістом, мали розробити браузерне програмне забезпечення. Власне фізичними задачами, для яких програмне забезпечення дозволить виконувати розрахунки параметрів, $є$ розтяг-стиснення металевих стержнів постійного та змінного перерізу. 
Спочатку студенти працювали над розробкою технічного завдання проекту, складали план виконання робіт та їх розподіл між учасниками команди. За результатами цього етапу у 2018-2019 н.р. студенти заповнювали Google-форму проміжного звіту.

На захист проекту було потрібно представити діюче програмне забезпечення та продемонструвати коректність його роботи На реалізацію проекту відводилося 6-7 тижнів, оскільки час реалізації проекту потрібно було узгоджувати для обох дисциплін. Робота над проектом ґрунтувалася на знаннях і навичках з вирішення відповідних задач прикладної механіки. Команди студентів охоплювали 3-4 особи з типовим розподілом завдань: комп'ютерне моделювання фрізичних процесів, пов'язаних з поведінкою металевого стержня при розтягу-стисненні; веб-програмування; графрічний дизайн сайту. На рис. 1 результати роботи однієї із програм, розроблених студентами.

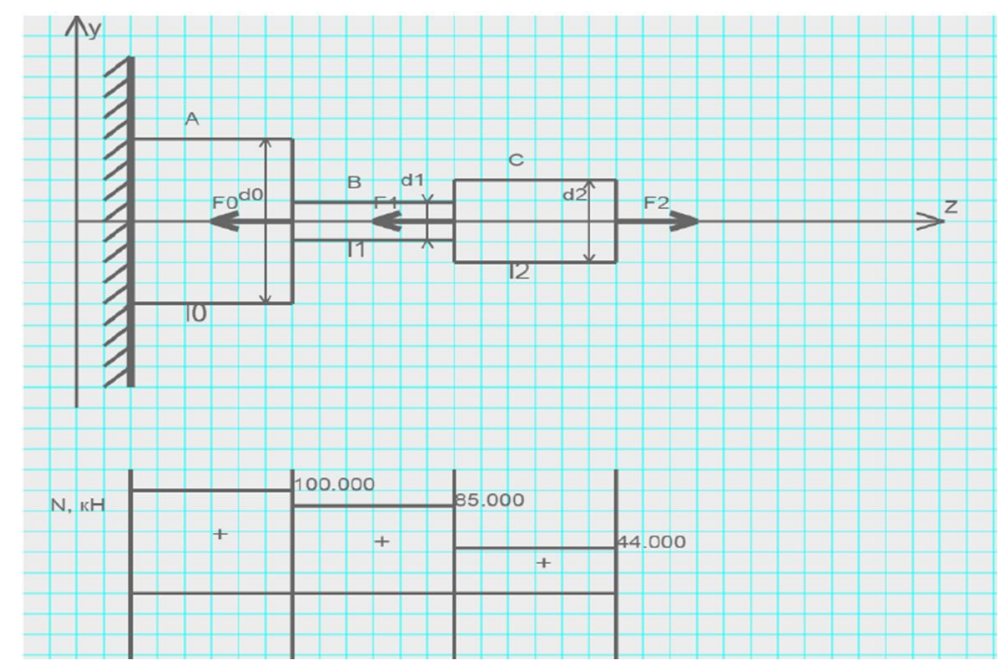

Рис. 1. Результат роботи розробленого студентами програмного забезпечення для розрахунку розтягу-стиснення стержня змінного перерізу

Отримані результати презентувалися наприкінці семестру, а їх оцінювання здійснювалося в рамках обох предметів. Для дисципліни «Прикладна механіка та основи конструювання» оцінювалася коректність роботи модулю, що відповідав за фрізичні розрахунки, а також зручність роботи 3 розробленим сайтом з погляду користувача, а саме: наявність модулю побудови епюри повздовжніх сил на навантажень; можливість бачити не тільки остаточний результат розрахунків, а й проміжні обчислення; можливість завантажувати отриманий розв'язок у форматі pdf, включаючи розрахунки й графічне зображення стержня, прикладених сил і побудованих епюр.

Протягом 2017-2019 н.р. у дослідженні взяли участь 34 студенти (13 осіб у 2017-2018 н.р. і 21 у 2018-2019 н.р.), які після презентації отриманих результатів заповнювали анкету.

Таким чином, загальні засади на яких ґрунтувалося упровадження обох проектів $є$ подібними. Ключовою відмінністю $є$ мультидисциплінарна тематика Проекту 2. Перевагами такого вибору $€$ можливість оптимізувати навантаження студентів, які працюють одночасно над проектом із двох дисциплін. На загальному рівні такий підхід відповідає ідеям гібридного проектно орієнтованого навчання [29].

\section{III Результати}

у 2017-2018 навчальному році в експериментальному дослідженні взяли участь 28 студентів, у 2018-2019 навчальному році - 42 студенти. Опитування студентів було анонімним і здійснювалося по завершенню роботи над проектними завданнями. Респондентам пропонувалося заповнити паперовий або електронний варіант анкети, а отримані дані було опрацьовано з використанням сервісів Google Form i MS Excel.

Анкета, запропонована студентам під час Проекту 1, включала наступні твердження (Табл. 2). Студенти мали обрати одну з опцій, для оцінки власного сприйняття наведених тверджень: геть незгодний, незгодний, не визначився, згодний, цілком згодний. 
Табл. 2. Перелік запитань анкети з виділеними категоріями тверджень

\begin{tabular}{|c|c|c|c|c|c|c|}
\hline №3/ח & Твердження & 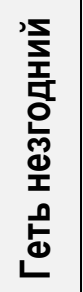 & 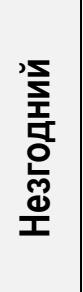 & 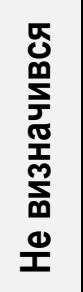 & 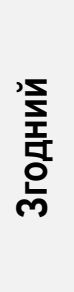 & 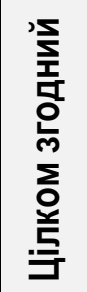 \\
\hline 1 & Проект був складним для реалізації & & & & & \\
\hline 2 & Проект був корисний для отримання нових знань та умінь & & & & & \\
\hline 3 & На виконання проекту було виділено достатньо часу & & & & & \\
\hline 4 & Я став краще розуміти цей предмет & & & & & \\
\hline 5 & Мені сподобалося працювати в команді & & & & & \\
\hline 6 & Я допомагав іншим працювати над проектом & & & & & \\
\hline 7 & Інші учасники команди допомагали мені зрозуміти матеріал & & & & & \\
\hline 8 & Я хотів би працювати над іншими проблемами з цією командою & & & & & \\
\hline 9 & Я навчився відстоювати власну позицію & & & & & \\
\hline 10 & Я навчився краще презентувати отримані результати & & & & & \\
\hline 11 & Я навчився краще знаходити та опрацьовувати інформацію & & & & & \\
\hline 12 & $\begin{array}{l}\text { Я навчися краще співпрацювати та спілкуватися } 3 \text { іншими } \\
\text { студентами }\end{array}$ & & & & & \\
\hline
\end{tabular}

Перша категорія тверджень визначала ставлення студентів до виконання самого проекту, а саме: чи складним був проект для реалізації, чи достатньо було відведено часу на його виконання, чи був проект корисним для отримання нових знань, чи допоміг проект краще зрозуміти дисципліну (рис. 2).

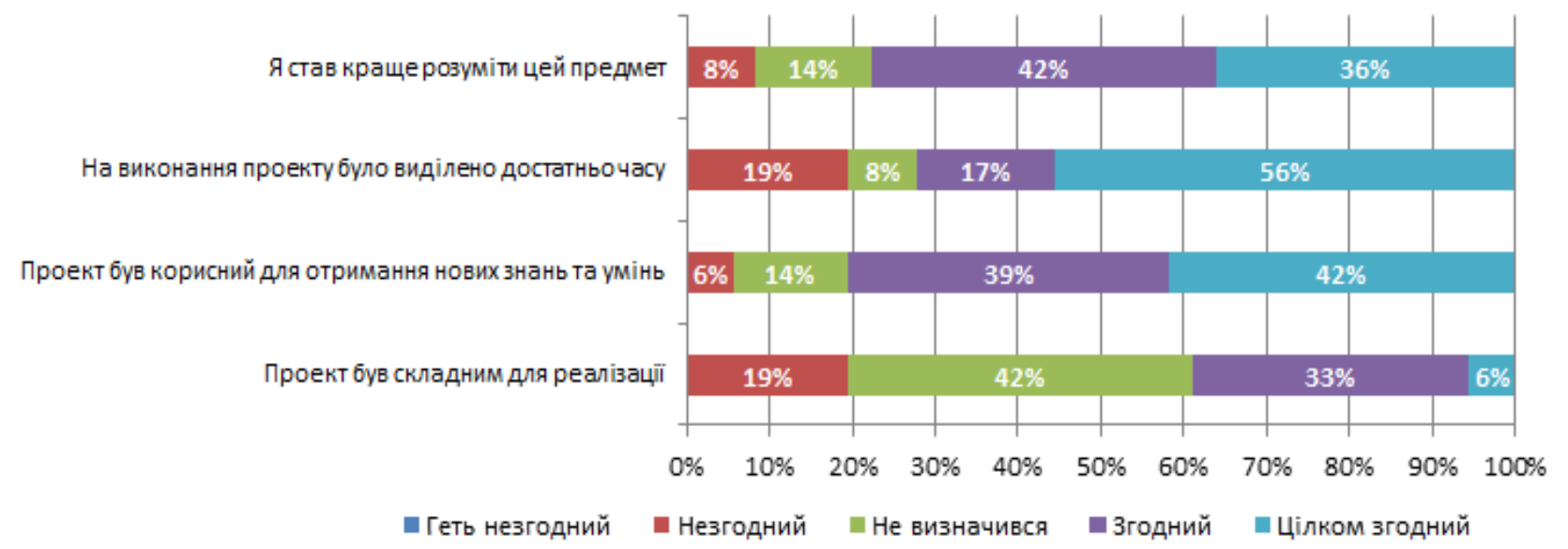

Рис. 2. Представлення результатів анкетування за першою категорією тверджень

Загалом, 39\% студентів зазначили що мали певні складності в реалізації проекту, що можна пояснити недостатньою кількістю досвіду роботи в команді. $81 \%$ вважають таку роботу корисною для отримання нових знань та умінь.

Друга категорія тверджень дає змогу визначити готовність студентів до роботи в команді, їх готовність надати допомогу колегам та отримати зворотну допомогу від них (рис. 3).

Загалом майже всі респонденти зазначили, що їм сподобалось працювати в команді. Такого результату досягнуто через самостійне об'єднання студентів у групи для роботи над поставленою задачею. Як зазначалося вище, об'єднання людей за спільними інтересами сприяє вільнішому та природнішому спілкуванню в межах групи, а відповідно і підвищує ефективність роботи кожного члена команди. 
Я хотів би працювати над іншими проблемами 3 цією командою

Інші учасники команди допомагали мені зрозуміти матеріал

Я допомагав іншим працювати над проектом

Мені сподобалося працювати в команді

- Геть незгодний

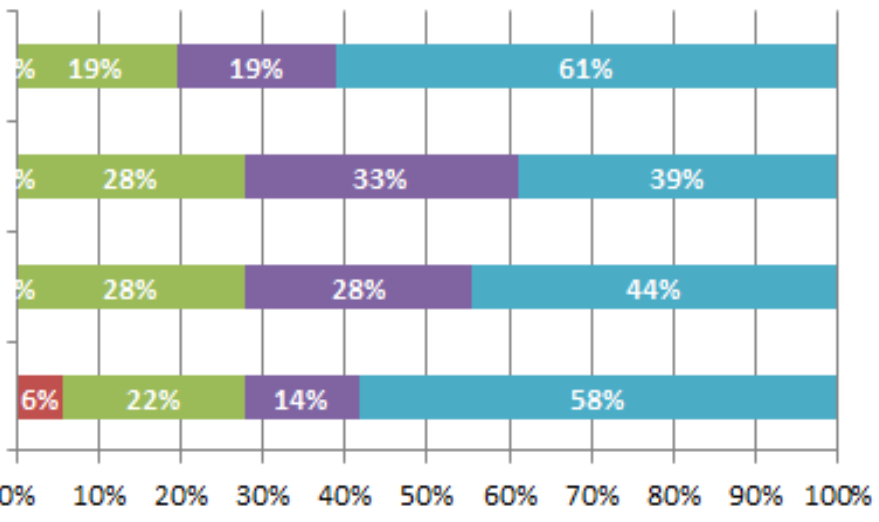

- Незгодний

Ше визначився

в Згодний

Шілком згодний

Рис. 3. Представлення результатів анкетування за другою категорією тверджень

Третя категорія тверджень визначала рівень розвитку власних якостей особистості студента, а саме рівень самоорганізації, здатність приймати рішення, презентувати результати роботи.

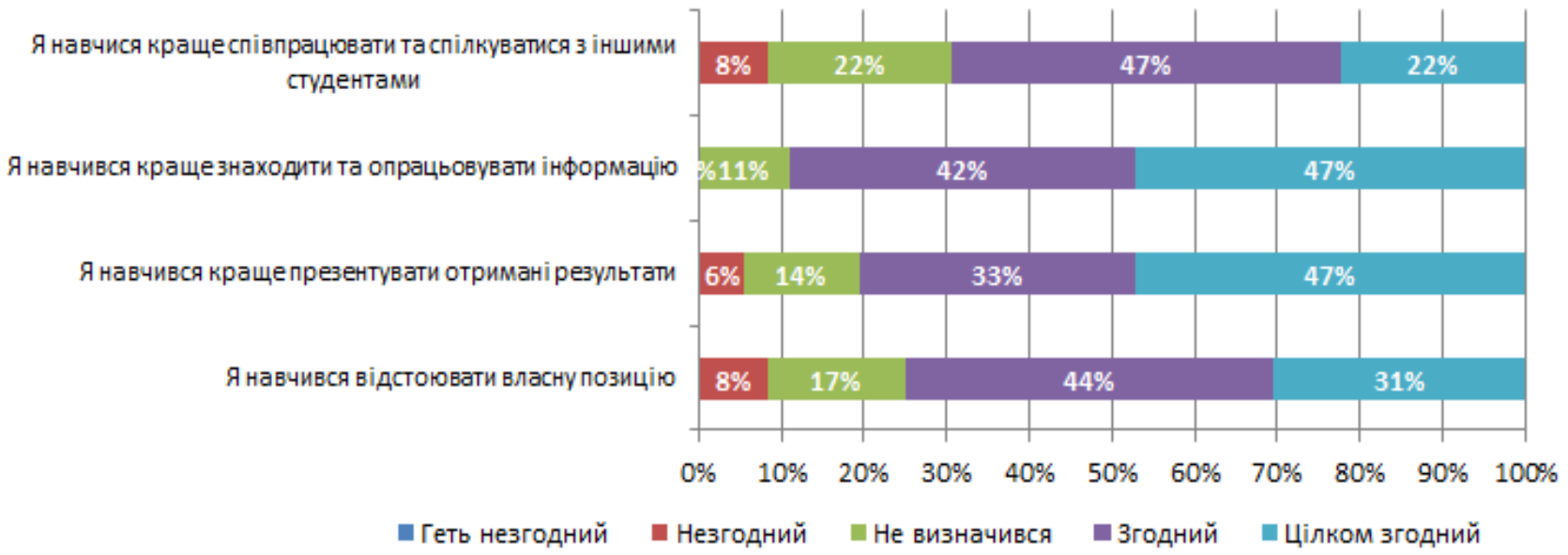

Рис. 4. Представлення результатів анкетування за третьою категорією тверджень

Для оцінки ефективності використання проектної діяльності було проведено тестування за матеріалами лекційних занять та визначено успішність їх засвоєння до та після виконання проектів студентами. Варто відзначити, що більша частина студентів засвоїла дисципліну на достатньому рівні (успішність склала >50\%), а для частини студентів спостерігалось істотне покращення рівня знань після роботи над проектом. Відчутне зменшення успішності прослідковувалось у студентів, які не приймали участь у роботі над проектами (студенти, що з тих чи інших причин, не примкнули до жодної робочої групи та працювали над виконанням завдань індивідуально).

Для Проекту 2 було підготовлено подібну анкету. Частина запитань стосувалася перебігу реалізації проекту. Майже 68\% (23 особи) респондентів відзначили, що робота над проектом була для них цікавим і помірно складним завданням. Студенти вказали, що часу на виконання завдання було достатньо. Однак, 44\% студентів (15 осіб) зазначили, що на початковому етапі їх бракувало детальних інструкцій щодо реалізації проекту.

Також, ми попросили студентів визначити, які якості були важливими для успішної реалізації їх проектного завдання. Наведені в опитувальнику твердження студенти мали оцінити за шкалою від 1 до 5, де "1" відповідає "зовсім не важлива", "2" - "скоріше не важлива", "3" - "помірно важлива", "4" "скоріше важлива", "5" - "критично важлива". У табл. 3 наведено запропоновані твердження та отримані результати. 
Табл. 3. Результати оцінювання студентами важливості компетентностей

\begin{tabular}{|c|c|c|c|}
\hline №3/ח & Твердження & $\begin{array}{l}\text { Середнє } \\
\text { значення }\end{array}$ & $\begin{array}{l}\text { Стандартне } \\
\text { відхилення }\end{array}$ \\
\hline 1 & $\begin{array}{l}\text { Здатність до пошуку, оброблення та аналізу } \\
\text { інфоормації з різних джерел }\end{array}$ & 3,76 & 0,66 \\
\hline 2 & Здатність працювати в команді & 4,12 & 0,86 \\
\hline 3 & $\begin{array}{l}\text { Здатність спілкуватися й презентувати власні } \\
\text { результати }\end{array}$ & 4,30 & 0,81 \\
\hline 4 & $\begin{array}{l}\text { Здатність застосовувати знання в практичних } \\
\text { ситуаціях }\end{array}$ & 3,82 & 0,85 \\
\hline 5 & Здатність планувати та управляти часом & 3,82 & 0,98 \\
\hline 6 & 3датність бути критичним та самокритичним & 3,88 & 0,86 \\
\hline 7 & $\begin{array}{l}\text { Здатність вчитися і бути сучасно навченим (у тому } \\
\text { числі здатність навчатися самостійно) }\end{array}$ & 3,76 & 0,79 \\
\hline
\end{tabular}

У третій частині опитування студенти оцінювали як змінилися їх якості після завершення проекту. Для оцінювання використовувалася 5-точкова шкала, де "1" відповідає "зовсім не змінилися" до "5" "відчутно змінилися". Таблиця 4 містить пропоновані твердження та результати самооцінювання студентами власних якостей.

Табл. 4. Результати самооцінювання студентами власних якостей

\begin{tabular}{|c|c|c|c|}
\hline №3/п & Твердження & $\begin{array}{l}\text { Середнє } \\
\text { значення }\end{array}$ & $\begin{array}{l}\text { Стандартне } \\
\text { відхилення }\end{array}$ \\
\hline 1 & Фундаментальні знання з основних дисциплін & 3,82 & 0,88 \\
\hline 2 & $\begin{array}{l}\text { Вміння застосовувати отримані знання на практиці } \\
\text { для розв'язку профресійних задач }\end{array}$ & 4,00 & 0,94 \\
\hline 3 & $\begin{array}{l}\text { Вміння планувати свої дії і час, керувати } \\
\text { інженерними проектами }\end{array}$ & 3,79 & 0,89 \\
\hline 4 & $\begin{array}{lll}\text { Вміння } & \text { використовувати різні } \\
\text { інфформації і працювати з ними } & & \\
\end{array}$ & 4,12 & 0,55 \\
\hline 5 & Вміння працювати як учасник команди & 4,18 & 0,92 \\
\hline 6 & $\begin{array}{l}\text { Розуміння просесійної відповідальності (безпека, } \\
\text { екологія, соціальна сфрера) }\end{array}$ & 3,82 & 1,04 \\
\hline 7 & $\begin{array}{l}\text { Вміння презентувати власну діяльність та її } \\
\text { результати }\end{array}$ & 4,15 & 0,83 \\
\hline 8 & Комунікативні якості & 4,39 & 0,79 \\
\hline
\end{tabular}

Співставляючи результати опитування (табл. 3 і табл. 4) та компетентності, наведені у таблиці 1 , зазначимо, що максимальних змін зазнали міжособистісні та системні загальні компетентності. Причому, саме роль міжособистісних компетентностей студенти оцінили найвище.

\section{IV Обговорення}

Застосування проектно-орієнтованих підходів до навчання STEM-дисциплін $€$ актуальною практикою в багатьох університетах світу [30-32]. У випадку Черкаського національного університету імені Богдана Хмельницького при підготовці студентів інженерної спеціальності 151 Автоматизація та комп'ютерно-інтегровані технології, поширеною $€$ практика проектно-орієнтованого навчання студентів випускних курсів, коли групові проекти реалізовуються при написанні курсових чи бакалаврських робіт 
[33]. Однак, як показує світовий досвід, нагальним завданням стає залучення до проектної діяльності студентів молодших курсів [3]. Окремий інтерес становлять дослідження, присвячені впровадженню проблемно- і проектно-орієнтованого навчання для вибраних фрізичних курсів, зокрема «Прикладної механіки», «Термодинаміки», «Інженерної теплотехніки» тощо [34-36].

Серед ключових завдань нашого дослідження було визначення того як студенти молодших курсів інженерної спеціальності сприймають впровадження проектно-орієнтованих підходів при навчанні STEM-дисциплін й оцінюють перебіг проектів. Зазначимо, що для студентів, які долучилися до дослідження, це був перший досвід проектної діяльності. Однак, продемонстроване студентами сприйняття проектної діяльності, як складової навчання STEM-дисциплін, є загалом позитивним, що підтверджується результатами опитування.

У випадку обох проектів студенти відзначили істотний вплив проектної діяльності на міжособистісні та системні загальні компетентності, зокрема, командну роботу, навички комунікації, уміння працювати з інформацією. Подібні результати підтверджуються низкою досліджень щодо впровадження проектно-орієнтованого навчання у вищій школі, мета-аналіз яких здійснено П. Гуо та ін. [37]. Як зазначають автори мета-дослідження, що опрацювали й узагальнили результати наведені в 76 публікаціях, позитивний вплив саме на формування загальних компетентностей, було відзначено в більшості робіт. У сфері інженерної освіти, вплив проектно-орієнтованого навчання на розвиток навичок застосування знань у практичних ситуаціях, командну роботу, навички презентації отриманих результатів, підтверджується низкою статей [38, 32, 3].

До проблемних моментів слід віднести труднощі, які для студентів виникали саме на етапі самостійного планування ходу виконання проекту. Однією з причин цього $є$ відсутність попереднього досвіду й попередньої практики реалізації студентських проектів. А у випадку студентів молодших курсів, брак такого досвіду, на жаль, зв'язаний із загальною спрямованістю середньої освіти на теоретичну підготовку та сумативні методики оцінювання. У випадку Проекту 2, у кожному з навчальних років, одна з команд студентів не змогла представити повноцінні результати проектів. У обох випадках причиною цього була ситуація, коли один із учасників команди не виконує визначену частину завдання або і втрачає контакт з командою повністю. Способом подолати труднощі такого типу й допомогти студентам "не втратити" проект, є проміжні звіти, що й планується застосовувати в подальшому. Окрім того, тематика проектів повинна бути актуальною, реалістичною у виконанні, а запланована організація реалізації проекту має припускати його гнучкість і внесення змін у процес виконання [35]. Теми проекту можуть бути запропоновані як викладачем, так і самими студентами. Таким чином студенти самі роблять свій вибір і виявляють ініціативу, в залежності від їх інтересів та можливостей.

У випадку викладачів доволі істотним є збільшення навантаження принаймні на першій ітерації упровадження проекту. Це пов'язано, зокрема, з тим, що забезпечення ефективного підтримки студентів на етапі реалізації проекту вимагає від викладача не лише глибоких знань і умінь з предмету, а й розвинутих загальних компетентностей і уміння використовувати сучасні засоби інформаційнокомунікаційних технологій для підтримки надійної та ефективної комунікації [30, 31].

Наразі міждисциплінарне навчання розглядається як важлива складова підготовки сучасних інженерів [32, 39]. "Перехід" між дисциплінами трактується як спосіб диверсифікації професійних якостей та підвищення конкурентоспроможності випускника на ринку праці. Попри це не існує єдиного алгоритму та підходу до його впровадження у практику. Перевагами впровадження мультидисциплінарних проектів у випадку нашого дослідження, виявилася можливість оптимізувати навантаження студентів, які працюють одночасно над проектом із двох дисциплін і посилити мотивацію до вивчення дисциплін STEM-циклу, що доволі часто розглядаються студентами як другорядні, у порівнянні з ІТ-дисциплінами.

Зазначимо, що навіть у випадку монодисциплінарного проекту, викладач має формулювати комплексні програмні результати, виділяючи не тільки фрахові, а й загальні компетентності. Фактично, кожен проект отримує міждисциплінарну складову. У практиці проектної діяльності студенти отримують i, що дуже важливо, відразу ж застосовують на практиці інформацію, про командну роботу - спілкування в команді, розподіл обов'язків; управління - планування завдань та часу їх виконання; комунікації підготовка виступу, презентації, усний виступ; інформаційно-комунікаційних технологій - програмні засоби комунікації та колективної роботи. 


\section{V Висновки}

Досвід впровадження інженерних проектів для студентів молодших курсів у рамках навчання STEM-дисциплін $€$ корисною практикою, що має позитивне сприйняття студентами і впливає на їх мотивацію до опанування STEM-дисциплін. У випадку впровадження проектно-орієнтованого навчання для студентів молодших курсів, мова йде не про зміну переліку предметів, а, що набагато важливіше, про зміну підходів до навчання й викладання в цілому, коли потреби студента, його мотиваційні фактори стають аспектом обов'язковим до врахування. За результатами самооцінювання студентів, у ході виконання проектних завдань відзначено підвищення рівня сфрормованості навичок командної роботи, комунікації та роботи з інфрормацією.

Роботу виконано за підтримки МОН України (держ. реєстрац. номер 0117U003909).

\section{Бібліографрічні посилання}

1. Bourn, D., \& Neal, I. The Global Engineer: Incorporating global skills within UK higher education of engineers. London: Department for International Development / Institute of Education, University of London, 2008. URL: https://discovery.ucl.ac.uk/id/eprint/10000839/. (дата звернення: 25.05.2020).

2. World Economic Forum. The Future of Jobs Report 2018. Geneva, Switzerland: World Economic Forum, 2018. URL: http://www3.weforum.org/docs/WEF_Future_of_Jobs_2018.pdf. (дата звернення: 25.05.2020).

3. Alves, A. C., Moreira, F., Carvalho, M. A., Oliveira, S., Malheiro, M. T., Brito, I., . . . Teixeira, S. Integrating Science, Technology, Engineering and Mathematics contents through PBL in an Industrial Engineering and Management first year program. Production, 29, 2019. doi:10.1590/0103-6513.20180111

4. Lawrence, K. Developing Leaders in a VUCA Environment. UNC Kenan-Flagler Business School, 2013. URL: https://www.emergingrnleader.com/wp-content/uploads/2013/02/developing-leaders-in-a-vuca-environment.pdf. (дата звернення: 25.05.2020).

5. Passow, H. J., \& Passow, C. H. What Competencies Should Undergraduate engineering Programs Emphasize? A Systematic Review / Journal of Engineering Education, 2017. 106(3). P. 475-526. doi:10.1002/jee.20171

6. Graham, R. The Global State of the Art in Engineering Education. Cambridge, MA, USA: Massachusetts Institute of Technology, 2018.

7. SCM. Graduates of Ukrainian Higher Educational Institutions: Stakeholders View, 2012. URL: https://www.yourcompass.org/docs/Employees\%20on\%20University_Graduates.pdf. (дата звернення: 25.05.2020).

8. SCM. Employment Experience of Higher Educational Institutions Graduates: Stakeholders and Graduates View, 2013. URL: http://www.slideshare.net/bestuniverua/ss-27208268. (дата звернення: 25.05.2020).

9. Зінченко, А. Г., Саприкіна, М. А. Навички для України 2030: погляд бізнесу. Київ: ТОВ "Видавництво "Юстон", 2016.

10. Chen, J., Kolmos, A., \& Du, X. Forms of implementation and challenges of PBL in engineering education: a review of literature / European Journal of Engineering Education, 2020. doi:10.1080/03043797.2020.1718615

11. Луценко, Г. В. Теоретико-методичні засади професійної підготовки майбутніх інженерів в умовах проектно орієнтованого навчання. (Дис. доктора пед. наук). Черкаси: Черкаський національний університет імені Богдана Хмельницького, 2019.

12. Kolmos, A. Reflection on Project Work and Problem-Base Learning / European Journal of Engineering Education, 1996. 21(2). P. 141-148.

13. Helle, L., Tynjala, P., \& Olkinuora, E. Project-based learning in post-secondary education - theory, practice and rubber sling shots / Higher education, 2006. (51). P. 287-314. doi:10.1007/s10734-004-6386-5

14. De Graaf, E., \& Kolmos, A. Characteristics of problem-based learning / International Journal of Engineering Education, 2003. 19(5). P. 657-662.

15. Prince, M. J., \& Felder, R. M. Inductive Teaching and Learning Methods: Definitions, Comparisons, and Research Bases / Journal of Engineering Education, 2006. 95(2). P. 123-138. doi:10.1002/j.2168-9830.2006.tb00884.x

16. Knoll, M. The Project Method: Its Vocational Education Origin and International Development / Journal of Industrial Teacher Education, 1997. 34(3). P. 59-80.

17. Dym, C., Agogino, A., Eris, O., Frey, D., \& Leifer, L. Engineering Design Thinking, Teaching, and Learning / Journal of Engineering Education, 2005. 94(1). P. 103-120. doi:10.1002/j.2168-9830.2005.tb00832.x

18. Crawley, E. F., Malmqvist, J., Ostlund, S., Brodeur, D. R., \& Edstrom, K. Rethinking Engineering Education: The CDIO Approach.2nd ed. Verlag: Springer, 2014.

19. Jamison, A., Kolmos, A., \& Holgaard, J. E. Hybrid Learning: An Integrative Approach to Engineering Education / Journal of Engineering Education, 2014. 103(2). P. 252-273. doi:10.1002/jee.20041

20. Schell, W., Sobek II, D. K., \& Velazquez, M. A. Educating Tomorrow's Engineer: Adding Flexibility Through Student-Defined Electives / Quality Approaches in Higher Education, 2011. 7(1). P. $12-22$.

21. Kolmos, A., Hadgraft, R. G., \& Holgaard, J. E. Response strategies for curriculum change in engineering / International Journal Technology and Design Education, 2016. 26(3). P. 391-411. doi:10.1007/s10798-015-9319-y

22. Huet, I. Research-based education as a model to change the teaching and learning environment in STEM disciplines I European Journal of Engineering Education, 2017. 45(3). P. 725-740. doi:10.1080/03043797.2017.1415299 
23. Cohen, L., Manion, L., \& Morrison, K. Research Methods in Education. Abingdon: Routledge, 2007.

24. Dresch, A., Lacerda, D. P., \& Miguel, P. A. A Distinctive Analysis of Case Study, Action Research and Design Science Research / Review of Business Management, 2015. 17(56). P. 1116-1133. doi:10.7819/rbgn.v17i56.2069

25. Denzin, N. K. The Research Act. Urbana-Champaign: University of Illinois, 1989.

26. Shinde, V. Design of Course Level Project Based Learning Models for an Indian Engineering Institute: An assessment of students' learning experiences and learning outcomes (PhD Thesis). Aalborg: Aalborg University, 2014.

27. Захарченко, В. М., Луговий, В. І., Рашкевич, Ю. М., Таланова, Ж. В. Розроблення освітніх програм. Методичні рекомендації. (В. Г. Кремінь, Ред.) Київ: ДП НВЦ "Пріоритети", 2014.

28. Fini, H. E., Awadallah, F., Parast, M. M., \& Abu-Lebdeh, T. The impact of project-based learning on improving student learning outcomes of sustainability concepts in transportation engineering courses / European Journal of Engineering Education, 2018. 43(3). P. 473-488. doi:10.1080/03043797.2017.1393045

29. Kolmos, A., de Graaff, E., \& Du, X. Diversity of PBL: - PBL Learning Principles and Models / Research on PBL Practice in Engineering Education, 2009. P. 9-21.

30. Lima, R. M., Carvalho, D., Flores, M. A., \& Van Hattum-Janssen, N. A case study on project led education in engineering: students' and teachers' perception / European Journal of Engineering Education, 2007. 32(3). P. 337-347. doi:10.1080/03043790701278599

31. Alves, A. C., Sousa, R. M., Fernandes, S., Cardoso, E., \& Carvalho, M. A. Teacher's experiences in PBL: implications for practice / European Journal of Engineering Education, 2015. 41(2). P. 123-141. doi:10.1080/03043797.2015.1023782

32. Costa, A. R., Ferreira, M., Barata, A., Viterbo, C., Rodrigues, J. S., \& Magalhaes, J. Impact of interdisciplinary learning on the development of engineering students' skills / European Journal of Engineering Education, 2018. 44(4). P. 589-601. doi:10.1080/03043797.2018.1523135

33. Lutsenko, G. V. Case study of a problem-based learning course of project management for senior engineering students / European Journal of Engineering Education, 2018. 43(6). P. 895-910. doi:10.1080/03043797.2018.1454892

34. Lape, N. K. Tiered Scaffolding of Problem-Based Learning Techniques in a Thermodynamics Course / ASEE Annual Conference \& Exposition. Vancouver, B.C., Canada, 2011.

35. Macho-Stadler, E., \& Elejalde-Garcia, M. J. Case study of a problem-based learning course of physics in a telecommunications engineering degree / European Journal of Engineering Education, 2013. 38(4). P. 408-416.

36. Martin, C. R., Ranalli, J., \& Moore, J. P. Problem-based Learning Module for Teaching Thermodynamic Cycle Analysis using PYroMat / ASEE Annual Conference \& Exposition, 2017. P. 13-27.

37. Guo, P., Saab, N., Post, L. S., \& Admiraal, W. A review of project-based learning in higher education: Student outcomes and measures / International Journal of Educational Research, 2020. 102. doi:10.1016/j.jer.2020.101586

38. Warnock, J. N., \& Mohammadi-Aragh, M. J. Case study: use of problem-based learning to develop students technical and professional skills / European Journal of Engineering Education, 2016. 41(2). P. 142-153. doi:10.1080/03043797.2015.1040739

39. Klaassen, R. G. Interdisciplinary education: a case study / European Journal of Engineering Education, 2018. doi:10.1080/03043797.2018.1442417

\section{References}

1. Bourn, D., \& Neal, I. (2008). The Global Engineer: Incorporating global skills within UK higher education of engineers. London: Department for International Development/ Institute of Education, University of London. Retrieved from http://eprints.ioe.ac.uk/839/1/Bourn2008Engineers.pdf

2. World Economic Forum. (2018). The Future of Jobs Report 2018. Geneva, Switzerland: World Economic Forum. Retrieved from http://www3.weforum.org/docs/WEF_Future_of_Jobs_2018.pdf.

3. Alves, A. C., Moreira, F., Carvalho, M. A., Oliveira, S., Malheiro, M. T., Brito, I., . . Teixeira, S. (2019). Integrating Science, Technology, Engineering and Mathematics contents through PBL in an Industrial Engineering and Management first year program. Production, 29. doi:10.1590/0103-6513.20180111

4. Lawrence, K. (2013). Developing Leaders in a VUCA Environment. UNC Kenan-Flagler Business School. Retrieved from https://www.emergingrnleader.com/wp-content/uploads/2013/02/developing-leaders-in-a-vuca-environment.pdf

5. Passow, H. J., \& Passow, C. H. (2017). What Competencies Should Undergraduate engineering Programs Emphasize? A Systematic Review. Journal of Engineering Education, 106(3), 475-526. doi:10.1002/jee.20171

6. Graham, R. (2018). The Global State of the Art in Engineering Education. Cambridge, MA, USA: Massachusetts Institute of Technology.

7. SCM. (2012). Graduates of Ukrainian Higher Educational Institutions: Stakeholders View. Retrieved from https://www.yourcompass.org/docs/Employees\%20on\%20University_Graduates.pdf

8. SCM. (2013). Employment Experience of Higher Educational Institutions Graduates: Stakeholders and Graduates View". Retrieved from http://www.slideshare.net/bestuniverua/ss-27208268

9. Zinchenko, A. H., \& Saprykina, M. A. (2016). Navychky dlya Ukrayiny 2030: pohlyad biznesu. Kyyiv: TOV "Vydavnytstvo "Yuston". [in Ukrainian]

10. Chen, J., Kolmos, A., \& Du, X. (2020). Forms of implementation and challenges of PBL in engineering education: a review of literature. European Journal of Engineering Education. doi:10.1080/03043797.2020.1718615 
11. Lutsenko, H. V. (2019). Teoretyko-metodychni zasady profesiynoyi pidhotovky maybutnikh inzheneriv $v$ umovakh proektno oriyentovanoho navchannya. (Dys. doktora ped. nauk). Cherkasy: Cherkas'kyy natsional'nyy universytet imeni Bohdana Khmel'nyts'koho. [in Ukrainian]

12. Kolmos, A. (1996). Reflection on Project Work and Problem-Base Learning. European Journal of Engineering Education, 21(2), 141-148.

13. Helle, L., Tynjala, P., \& Olkinuora, E. (2006). Project-based learning in post-secondary education - theory, practice and rubber sling shots. Higher education(51), 287-314. doi:10.1007/s10734-004-6386-5

14. De Graaf, E., \& Kolmos, A. (2003). Characteristics of problem-based learning. International Journal of Engineering Education, 19(5), 657-662.

15. Prince, M. J., \& Felder, R. M. (2006). Inductive Teaching and Learning Methods: Definitions, Comparisons, and Research Bases. Journal of Engineering Education, 95(2), 123-138. doi:10.1002/j.2168-9830.2006.tb00884.x

16. Knoll, M. (1997). The Project Method: Its Vocational Education Origin and International Development. Journal of Industrial Teacher Education, 34(3), 59-80.

17. Dym, C., Agogino, A., Eris, O., Frey, D., \& Leifer, L. (2005). Engineering Design Thinking, Teaching, and Learning. Journal of Engineering Education, 94(1), 103-120. doi:10.1002/j.2168-9830.2005.tb00832.x

18. Crawley, E. F., Malmqvist, J., Ostlund, S., Brodeur, D. R., \& Edstrom, K. (2014). Rethinking Engineering Education: The CDIO Approach.2nd ed. Verlag: Springer.

19. Jamison, A., Kolmos, A., \& Holgaard, J. E. (2014). Hybrid Learning: An Integrative Approach to Engineering Education. Journal of Engineering Education, 103(2), 252-273. doi:10.1002/jee.20041

20. Schell, W., Sobek II, D. K., \& Velazquez, M. A. (2011). Educating Tomorrow's Engineer: Adding Flexibility Through StudentDefined Electives. Quality Approaches in Higher Education, 7(1), 12-22.

21. Kolmos, A., Hadgraft, R. G., \& Holgaard, J. E. (2016). Response strategies for curriculum change in engineering. International Journal Technology and Design Education, 26(3), 391-411. doi:10.1007/s10798-015-9319-y

22. Huet, I. (2017). Research-based education as a model to change the teaching and learning environment in STEM disciplines. European Journal of Engineering Education, 45(3), 725-740. doi:10.1080/03043797.2017.1415299

23. Cohen, L., Manion, L., \& Morrison, K. (2007). Research Methods in Education. Abingdon: Routledge.

24. Dresch, A., Lacerda, D. P., \& Miguel, P. A. (2015). A Distinctive Analysis of Case Study, Action Research and Design Science Research. Review of Business Management, 17(56), 1116-1133. doi:10.7819/rbgn.v17i56.2069

25. Denzin, N. K. (1989). The Research Act. Urbana-Champaign: University of Illinois.

26. Shinde, V. (2014). Design of Course Level Project Based Learning Models for an Indian Engineering Institute: An assessment of students' learning experiences and learning outcomes (PhD Thesis). Aalborg: Aalborg University.

27. Zakharchenko, V. M., Luhovyy, V. I., Rashkevych, YU. M., \& Talanova, ZH. V. (2014). Rozroblennya osvitnikh prohram. Metodychni rekomendatsiyi. (V. H. Kremin', Red.) Kyyiv: DP NVTS "Priorytety". [in Ukrainian]

28. Fini, H. E., Awadallah, F., Parast, M. M., \& Abu-Lebdeh, T. (2018). The impact of project-based learning on improving student learning outcomes of sustainability concepts in transportation engineering courses. European Journal of Engineering Education, 43(3), 473-488. doi:10.1080/03043797.2017.1393045

29. Kolmos, A., de Graaff, E., \& Du, X. (2009). Diversity of PBL: - PBL Learning Principles and Models. In X. Du, P. de Graaff, \& A. Kolmos (Eds.), Research on PBL Practice in Engineering Education (pp. 9-21). Brill | Sense.

30. Lima, R. M., Carvalho, D., Flores, M. A., \& Van Hattum-Janssen, N. (2007). A case study on project led education in engineering: students' and teachers' perception. European Journal of Engineering Education, 32(3), 337-347. doi:10.1080/03043790701278599

31. Alves, A. C., Sousa, R. M., Fernandes, S., Cardoso, E., \& Carvalho, M. A. (2015). Teacher's experiences in PBL: implications for practice. European Journal of Engineering Education, 41(2), 123-141. doi:10.1080/03043797.2015.1023782

32. Costa, A. R., Ferreira, M., Barata, A., Viterbo, C., Rodrigues, J. S., \& Magalhaes, J. (2018). Impact of interdisciplinary learning on the development of engineering students' skills. European Journal of Engineering Education, 44(4), 589-601. doi:10.1080/03043797.2018.1523135

33. Lutsenko, G. V. (2018). Case study of a problem-based learning course of project management for senior engineering students. European Journal of Engineering Education, 43(6), 895-910. doi:10.1080/03043797.2018.1454892

34. Lape, N. K. (2011). Tiered Scaffolding of Problem-Based Learning Techniques in a Thermodynamics Course. ASEE Annual Conference \& Exposition. Vancouver, B.C., Canada.

35. Macho-Stadler, E., \& Elejalde-Garcia, M. J. (2013). Case study of a problem-based learning course of physics in a telecommunications engineering degree. European Journal of Engineering Education, 38(4), 408-416.

36. Martin, C. R., Ranalli, J., \& Moore, J. P. (2017). Problem-based Learning Module for Teaching Thermodynamic Cycle Analysis using PYroMat. ASEE Annual Conference \& Exposition, (pp. 13-27). Columbus, $\mathrm{OH}$.

37. Guo, P., Saab, N., Post, L. S., \& Admiraal, W. (2020). A review of project-based learning in higher education: Student outcomes and measures. International Journal of Educational Research, 102. doi:10.1016/j.ijer.2020.101586

38. Warnock, J. N., \& Mohammadi-Aragh, M. J. (2016). Case study: use of problem-based learning to develop students technical and professional skills. European Journal of Engineering Education, 41(2), 142-153. doi:10.1080/03043797.2015.1040739

39. Klaassen, R. G. (2018). Interdisciplinary education: a case study. European Journal of Engineering Education. doi:10.1080/03043797.2018.1442417 


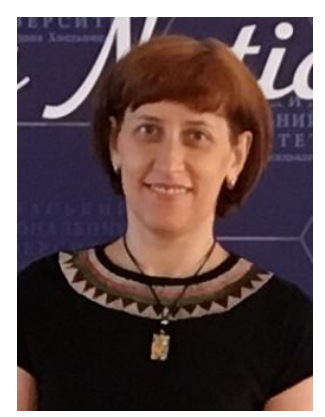

Луценко Галина Василівна,

Доктор педагогічних наук, доцент, доцент кафедри автоматизації та комп'ютерно-інтегрованих

технологій,

Черкаський національний університет імені Богдана Хмельницького,

79 , бульв. Шевченка, Черкаси

Тел. +38 (067) 277-02-79. E-mail: LutsenkoG@gmail.com

Lutsenko Galyna Vasylivna,

Doctor of Pedagogical Sciences, Associated Professor, Associated Professor of Department of

Automatization and Computer Integrated Technologies,

Bohdan Khmelnytsky National University of Cherkasy,

79, blvd. Shevchenko, Cherkasy

Tel. +38 (067) 277-02-79. E-mail: LutsenkoG@gmail.com

ORCID: 0000-0002-9727-7836

Researcher ID: Q-5027-2019

Scopus ID: 7003642282

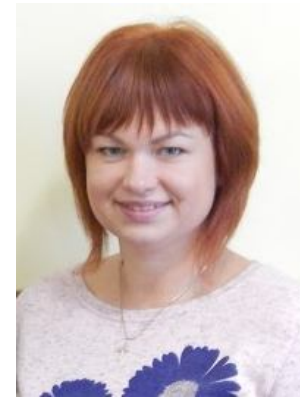

Подолян Оксана Миколаївна,

Кандидат фізико-математичних наук, старший викладач кафедри автоматизації та комп'ютерно-

інтегрованих технологій,

Черкаський національний університет імені Богдана Хмельницького,

79, бульв. Шевченка, Черкаси

Тел. +38 (093) 044-92-02. E-mail: ompodolyan@gmail.com

\section{Podolian Oksana Mykolaivna,}

$\mathrm{PhD}$, Sciences, Senior Lecturer of Department of Automatization and Computer Integrated

Technologies,

Bohdan Khmelnytsky National University of Cherkasy,

79 , blvd. Shevchenko, Cherkasy

Tel. +38 (093) 044-92-02. E-mail: ompodolyan@gmail.com

ORCID: 0000-0003-4082-1519

Researcher ID: F-1272-2019

Scopus ID: 35178283200

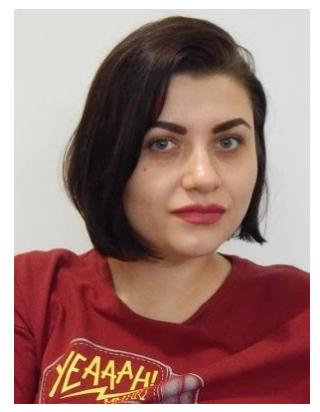

\section{Ожиндович Людмила Михайлівна,}

Провідний фрахівець кафедри автоматизації та комп'ютерно-інтегрованих технологій,

Черкаський національний університет імені Богдана Хмельницького,

79, бульв. Шевченка, Черкаси

Тел. +38 (096) 152-17-01. E-mail: fia.ozhyndovych@gmail.com

\section{Ozhyndovych Lyudmyla Mikhailivna,}

Leading specialist of Department of Automatization and Computer Integrated Technologies,

Bohdan Khmelnytsky National University of Cherkasy,

79, blvd. Shevchenko, Cherkasy

Tel. +38 (096) 152-17-01. E-mail: fia.ozhyndovych@gmail.com

ORCID: 0000-0001-7697-6948

\section{Citation (APA):}

Lutsenko, G., Podolian, O., Ozhyndovych, L. (2020). Project-based STEM-courses for engineering students. Engineering and Educational Technologies, 8 (2), 53-68. doi: https://doi.org/10.30929/2307-9770.2020.08.02.05

\section{Цитування (ДСТУ 8302:2015):}

Луценко Г. В., Подолян О. М., Ожиндович Л. М. Проектно-орієнтовані STEM-дисципліни для студентів інженерних спеціальностей / Інженерні та освітні технології. 2020. Т. 8. № 2. С. 53-68. doi: https://doi.org/10.30929/2307-9770.2020.08.02.05

Обсяе статmі: сторінок-16 ; умовних друк. аркушів - 2,318. 